\title{
ALOX5 wt Allele
}

National Cancer Institute

\section{Source}

National Cancer Institute. ALOX5 wt Allele. NCI Thesaurus. Code C68727.

Human ALOX5 wild-type allele is located in the vicinity of 10q11.2 and is approximately 72 $\mathrm{kb}$ in length. This allele, which encodes arachidonate 5-lipoxygenase protein, is involved in the regulation of leukotriene signaling. Mutations in the gene, which affect the enzymatic activity of the gene product, play a role in asthma, atherosclerosis and several cancers. 